\title{
Anti-Citrullinated Peptide/Protein Antibodies and Structural Prognosis of Rheumatoid Arthritis: Quantity Versus Quality
}

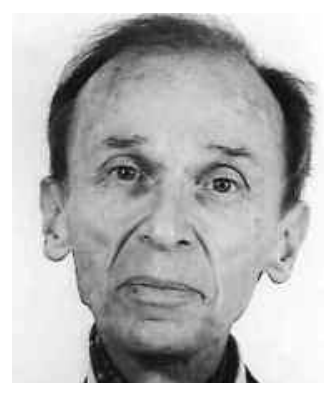

Anti-citrullinated peptide antibodies (ACPA) are the most specific known marker for rheumatoid arthritis (RA) in adults. ACPA develop several years before the first clinical manifestations of arthritis and are highly predictive of progression from undifferentiated arthritis to definite $\mathrm{RA}^{1}$, as demonstrated in several longitudinal cohort studies of patients with early undifferentiated arthritis. The presence of ACPA is among the 2010 American College of Rheumatology/European League Against Rheumatism criteria for persistent, nonerosive polyarthritis requiring methotrexate therapy. Of the 6 points needed to warrant methotrexate therapy, the presence of ACPA provides 2 points if the titer is low (2-3 times the upper limit of normal) and 3 points if the titer is high (more than 3 times the upper limit of normal). Thus, quantitative considerations are important when using ACPA for diagnostic purposes.

ACPA also help to predict outcomes. In cross-sectional and longitudinal cohort studies of patients with early RA, the presence of ACPA was independent from the disease phenotype (presentation and topographic distribution of the affected joints) but was significantly associated with disease activity $^{2}$, evaluated for instance using the Health Assessment Questionnaire score and, to an even greater extent, with structural disease progression evaluated using the Larsen radiographic score or, preferably, the Sharp score as modified by van der Heidje ${ }^{2,3}$.

An article by Shiozawa, et $a l^{4}$ in this issue of The Journal reports that a positive ELISA-cyclic citrullinated peptide antibody-2 (CCP) test for ACPA was associated with greater radiographic progression in a cohort of 396 patients with early RA $(<2$ yrs), compared to patients having negative tests for ACPA. Given that many patients with RA with ACPA also have IgM rheumatoid factors (IgM-RF), the authors considered the subgroup of 41 patients with ACPA but not IgM-RF. When the 2-year followup radiographs in this subgroup were compared to the 86 patients with neither ACPA nor IgM-RF, having ACPA was again associated with greater radiographic progression.
Although ACPA titer seems positively correlated with the modified Sharp score, the cumulative proportion of patients with joint destruction is not significantly different between RA patients with low titers and those with high titers. This result is at variance with findings reported in 2008 by Norwegian investigators who studied 238 patients with fairly recent RA at baseline (mean disease duration 2.3 yrs), including 125 patients for whom hand radiographs were available at baseline and 10 years later ${ }^{5}$. The odds ratio (OR) for radiographic progression increased from 2.5 (95\% CI 0.9-7.2) in the subgroup with low to moderate ACPA titers (as assessed using an anti-CCP test) to 9.9 (95\% CI 2.7-36.6) in those with high ACPA titers ${ }^{5}$. The available data, therefore, suggest that changes in either direction in the ACPA titer versus baseline have no value for predicting subsequent outcomes ${ }^{6}$.

Thus, the results discussed above are conflicting. No independent studies other than the one described above ${ }^{5}$ are available to date. Therefore, in the current state of knowledge, high ACPA titers cannot be used to predict a greater risk of radiographic progression compared to low titers. In addition, there was no adjustment for a number of confounding factors such as smoking history ${ }^{7}$ or lung disease ${ }^{8}$.

Apart from quantitative considerations, qualitative features of ACPA may help to predict joint damage severity. These features may include the ACPA isotype, the number of isotypes produced, the IgG subclass, the type of citrullinated protein targeted by the antibodies ${ }^{9,10}$, or even, for a given citrullinated protein, the epitopes present on the surface of the molecule or concealed within the molecule (cryptic epitopes) ${ }^{11}$. To date, published studies on ACPA isotypes and subclasses have been inconclusive.

Among all these features of ACPA, those investigated in the most advanced studies are the various citrullinated targets such as filaggrin, mutated vimentin ${ }^{12,13}$, alpha-enolase $^{14}$, fibrin and its peptides, myelin basic protein, Sa protein ${ }^{15}$, Epstein-Barr proteins ${ }^{16}$, binding immunoglobulin protein, and citrullinated collagen. Few studies compared

See ACPA, but not its titer, predicts RA severity, page 694

Personal non-commercial use only. The Journal of Rheumatology Copyright $\odot$ 2012. All rights reserved. 
the predictive value of the various ACPA present in the same serum, and qualitative studies focused on a small number of specificities $^{15,17,18,19,20}$. Most published studies used noncommercial, inhouse tests, which is an obstacle to replication of the findings.

Lastly, emphasis has recently been placed on antibodies that target homocitrullinated proteins (produced by conversion via carbamylation of lysine residues to homocitrulline residues). The joint prognosis in RA without ACPA but with anti-carbamylated protein antibodies seems similar to that of RA with ACPA/CCP, i.e., more severe than that of RA without either type of antibody ${ }^{21}$. Studies are needed to determine the specificity of anti-carbamylated protein antibodies compared to ACPA for diagnosing RA. However, these newly identified antibodies hold promise for predicting the outcome of early RA.

OLIVIER MEYER, MD, Service de Rhumatologie, APHP-Hôpital Bichat, 46 rue Henri Huchard, Paris, France

Address correspondence to Dr. Meyer.

E-mail: olivier.meyer@bch.aphp.fr

\section{REFERENCES}

1. van Venrooij WJ, van Beers JJ, Pruijn GJ. Anti-CCP antibodies: The past, the present and the future. Nat Rev Rheumatol 2011;7:391-8.

2. Miriovsky BJ, Michaud K, Thiele GM, O’Dell JR, Cannon GW, Kerr G, et al. Anti-CCP antibody and rheumatoid factor concentrations predict greater disease activity in men with rheumatoid arthritis. Ann Rheum Dis 2010;69:1292-7.

3. Ronnelid J, Wick MC, Lampa J, Lindblad S, Nordmark B, Klareskog L, et al. Longitudinal analysis of citrullinated protein/peptide antibodies (anti-CP) during 5 year follow up in early rheumatoid arthritis: Anti-CCP status predicts worse disease activity and greater radiological progression. Ann Rheum Dis 2005; 64:1744-9.

4. Shiozawa K, Kawasaki Y, Yamane T, Yoshihara R, Tanaka Y, Uto K, et al. Anticitrullinated protein antibody, but not its titer, is a predictor of radiographic progression and disease activity in rheumatoid arthritis. J Rheumatol 2012;39:694-700.

5. Syversen SW, Gaarder PI, Goll GL, Odegard S, Haavardsholm EA, Mowinckel P, et al. High anti-cyclic citrullinated peptide levels and an algorithm of four variables predict radiographic progression in patients with rheumatoid arthritis: Results from a 10-year longitudinal study. Ann Rheum Dis 2008;67:212-7.

6. Ursum J, Bos WH, van Dillen N, Dijkmans BA, van Schaardenburg D. Levels of anti-citrullinated protein antibodies and IgM rheumatoid factor are not associated with outcome in early arthritis patients: A cohort study. Arthritis Res Ther 2010;12:R8.

7. Klareskog L, Stolt P, Lundberg K, Kallberg H, Bengtsson C, Grunewald J, et al. A new model for an etiology of rheumatoid arthritis: Smoking may trigger HLA-DR (shared epitope)-restricted immune reactions to autoantigens modified by citrullination. Arthritis Rheum 2006;54:38-46.

8. Aubart F, Crestani B, Nicaise-Roland P, Tubach F, Bollet C, Dawidowicz K, et al. High levels of anti-cyclic citrullinated peptide autoantibodies are associated with co-occurrence of pulmonary diseases with rheumatoid arthritis. J Rheumatol 2011;38:979-82.
9. Chapuy-Regaud S, Nogueira L, Clavel C, Sebbag M, Vincent C, Serre G. IgG subclass distribution of the rheumatoid arthritis-specific autoantibodies to citrullinated fibrin. Clin Exp Immunol 2005;139:542-50.

10. van der Woude D, Syversen SW, van der Voort EI, Verpoort KN, Goll GL, van der Linden MP, et al. The ACPA isotype profile reflects long-term radiographic progression in rheumatoid arthritis. Ann Rheum Dis 2010;69:1110-6.

11. Sebbag M, Moinard N, Auger I, Clavel C, Arnaud J, Nogueira L, et al. Epitopes of human fibrin recognized by the rheumatoid arthritis-specific autoantibodies to citrullinated proteins. Eur J Immunol 2006;36:2250-63.

12. Nicaise Roland P, Grootenboer Mignot S, Bruns A, Hurtado M, Palazzo E, Hayem G, et al. Antibodies to mutated citrullinated vimentin for diagnosing rheumatoid arthritis in anti-CCP-negative patients and for monitoring infliximab therapy. Arthritis Res Ther 2008;10:R142.

13. Luime JJ, Colin EM, Hazes JM, Lubberts E. Does anti-mutated citrullinated vimentin have additional value as a serological marker in the diagnostic and prognostic investigation of patients with rheumatoid arthritis? A systematic review. Ann Rheum Dis 2010;69:337-44.

14. Lundberg K, Kinloch A, Fisher BA, Wegner N, Wait R, Charles P, et al. Antibodies to citrullinated alpha-enolase peptide 1 are specific for rheumatoid arthritis and cross-react with bacterial enolase. Arthritis Rheum 2008;58:3009-19.

15. Boire G, Cossette P, de Brum-Fernandes AJ, Liang P, Niyonsenga T, Zhou ZJ, et al. Anti-Sa antibodies and antibodies against cyclic citrullinated peptide are not equivalent as predictors of severe outcomes in patients with recent-onset polyarthritis. Arthritis Res Ther 2005; 7:R592-603.

16. Pratesi F, Tommasi C, Anzilotti C, Chimenti D, Migliorini P. Deiminated Epstein-Barr virus nuclear antigen 1 is a target of anti-citrullinated protein antibodies in rheumatoid arthritis. Arthritis Rheum 2006;54:733-41.

17. Innala L, Kokkonen H, Eriksson C, Jidell E, Berglin E, Dahlqust SR. Antibodies against mutated citrullinated vimentin are a better predictor of disease activity at 24 months in early rheumatoid arthritis than antibodies against cyclic citrullinated peptides. J Rheumatol 2008;35:1002-8.

18. van der Linden MP, van der Woude D, Ioan-Facsinay A, Levarht EW, Stoeken-Rijsbergen G, Huizinga TW, et al. Value of anti-modified citrullinated vimentin and third-generation anti-cyclic citrullinated peptide compared with second-generation anti-cyclic citrullinated peptide and rheumatoid factor in predicting disease outcome in undifferentiated arthritis and rheumatoid arthritis. Arthritis Rheum 2009;60:2232-41.

19. Snir O, Widhe M, von Spee C, Lindberg J, Padyukov L, Lundberg $\mathrm{K}$, et al. Multiple antibody reactivities to citrullinated antigens in sera from patients with rheumatoid arthritis: Association with HLA-DRB1 alleles. Ann Rheum Dis 2009;68:736-43.

20. Mathsson L, Mullazehi M, Wick MC, Sjoberg O, van Vollenhoven $\mathrm{R}$, Klareskog L, et al. Antibodies against citrullinated vimentin in rheumatoid arthritis: Higher sensitivity and extended prognostic value concerning future radiographic progression as compared with antibodies against cyclic citrullinated peptides. Arthritis Rheum 2008;58:36-45.

21. Shi J, Knevel R, Suwannalai P, van der Linden MP, Janssen GM, van Veelen PA, et al. Autoantibodies recognizing carbamylated proteins are present in sera of patients with rheumatoid arthritis and predict joint damage. Proc Natl Acad Sci USA 2011;108:17372-7.

J Rheumatol 2012;39:675-6; doi:10.3899/jrheum.120009 